(c) 2001 Plant Health Progress.

Accepted for publication 14 J une 2001. Published 9 July 2001.

\title{
The Impact of Plant Diseases on World Chocolate Production
}

J ohn H. Bowers and Bryan A. Bailey, Research Plant Pathologists, USDA, ARS, PSI Alternate Crops \& Systems Lab, Beltsville, MD 20705; Prakash K. Hebbar, Senior Research Associate, M\&M Mars, Inc. Research \& Development, Beltsville, MD 20705; Soumaila Sanogo, Research Associate, Wye Research \& Extension Center University of Maryland, Queenstown, MD 21658; Robert D.

Lumsden, Plant Pathologist and Collaborator, USDA, ARS, PSI Alternate Crops \& Systems Lab, Beltsville, MD 20705

Corresponding author: John H. Bowers. bowers)o@ba.ars.usda.gov

Bowers, J. H., Bailey, B. A., Hebbar, P. K., Sanogo, S., Lumsden, R. D. 2001. The impact of plant diseases on world chocolate production. Online. Plant Health Progress doi: 10.1094/PHP-2001-0709-01-RV.

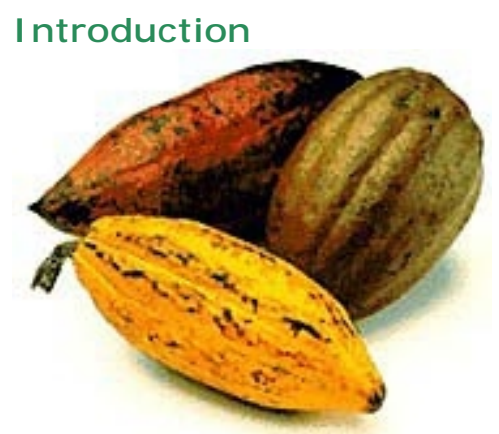

Fig. 1A. Pods of Theobroma cacao, which contain 30-40 seeds each that are harvested and processed into chocolate products.
Chocolate has its origins in ancient Central America where the Maya and the Aztecs cultivated the cacao tree (Theobroma cacao L.) (Figs. 1A to 1C) and extracted from the seeds or beans a highly prized drink (Figs. 2A,2B,3), which was called chocolatl, a precursor to our modern English word chocolate (41). Theobroma means the source of the "food of the gods," hence its scientific name Theo (god) and broma (food). The Spaniards, notably Hernan Cortez, introduced the drink to the Spanish royalty, but the bitter drink did not become popular for another one hundred years, when additives such as sugar, cinnamon, and chile peppers made the drink more palatable. Chocolate was the first mildly stimulating drink introduced to Europe, appearing even before coffee and tea.

The present-day popularity of chocolate and the drink cocoa needs no verification as attested to by the many "chocolate lovers" who especially look forward to occasions and national holidays when chocolate is traditionally given as a gift to loved ones and friends. The demand for chocolate is growing and the question now is will the world supply of a product that comes from a strictly tropical, rainforest-inhabiting tree will continue to meet the demand. Over the past two decades several important fungal diseases have gained considerable importance and pose a serious threat to the supply of chocolate (Fig. 4). 


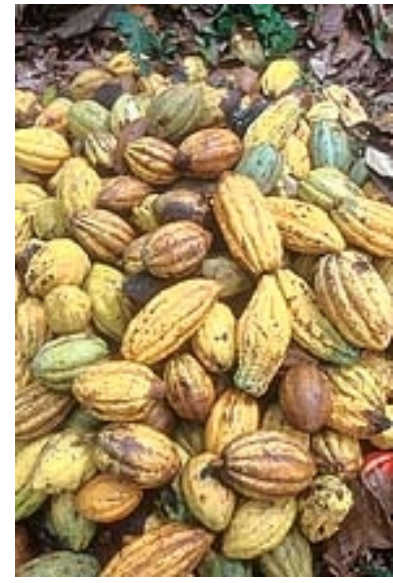

Fig. 1B. Cacao pods in the field in Brazil.

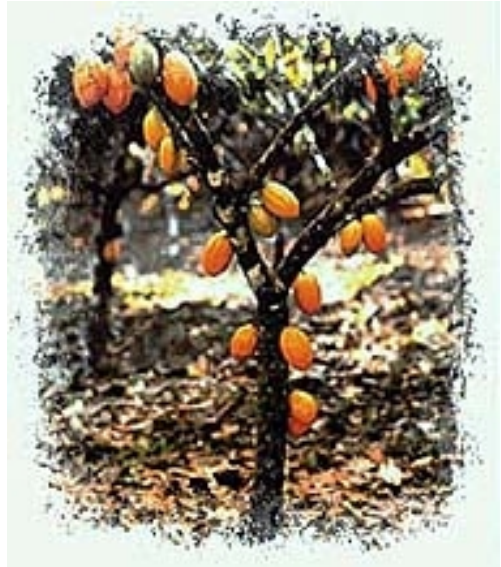

Fig. 1C. Healthy cacao tree with pods, which develop from flower cushions on the trunk of the tree.

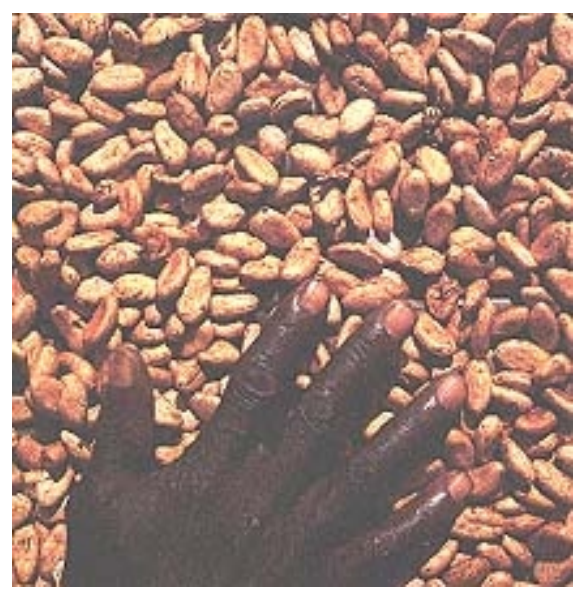

Fig. 2A. Cocoa beans (courtesy M\&M Mars, Inc.).

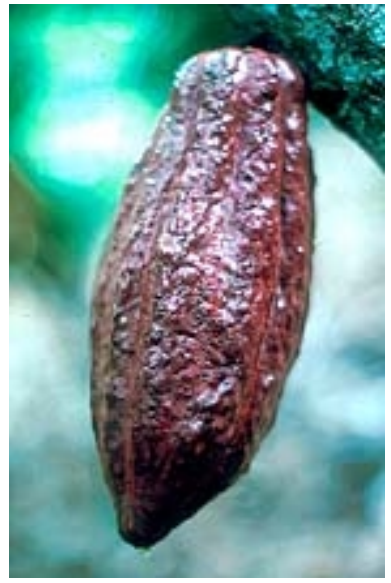

Fig. 3. Healthy cacao pod.

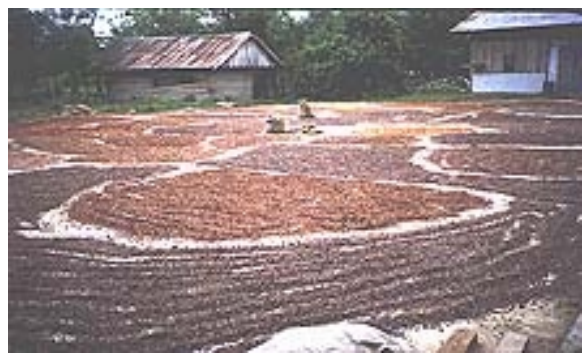

Fig. 2B. Cocoa beans drying in the sun (courtesy M\&M Mars, Inc.).

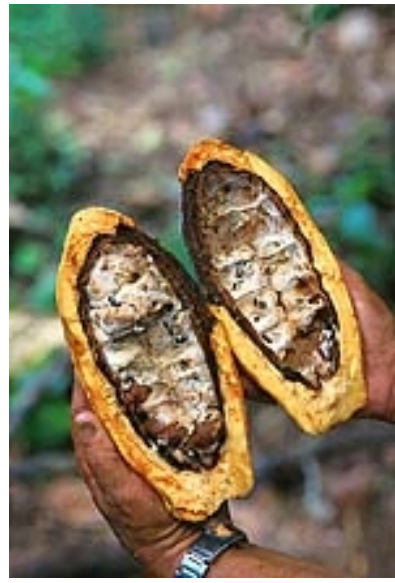

Fig. 4. Diseased pod with infected seeds.

Depending on where cacao is grown, one or more of three diseases (black pod, witches' broom, and frosty pod rot) may reach epiphytotic proportions that cause devastating losses (Table 1) $(8,12,36)$. 
Table 1. Estimated annual reduction in potential cocoa production by major diseases.

\begin{tabular}{|l|l|l|c|c|}
\hline \multirow{2}{*}{ Diseases } & \multicolumn{1}{|c|}{ Pathogen } & \multicolumn{1}{c|}{ Region } & \multicolumn{1}{c|}{$\begin{array}{c}\text { Reduced Production } \\
\text { (tons 1000) }\end{array}$} & (\$ million) $^{*}$ \\
\hline $\begin{array}{l}\text { Black } \\
\text { Pod }\end{array}$ & $\begin{array}{l}\text { Phytophthora } \\
\text { spp. }\end{array}$ & $\begin{array}{l}\text { Africa/Brazil/ } \\
\text { Asia }\end{array}$ & 450 & 423 \\
\hline $\begin{array}{l}\text { Witches' } \\
\text { Broom }\end{array}$ & $\begin{array}{l}\text { Crinipellis } \\
\text { perniciosa }\end{array}$ & Latin America & 250 & 235 \\
\hline $\begin{array}{l}\text { Frosty } \\
\text { Pod Rot }\end{array}$ & $\begin{array}{l}\text { Moniliophthora } \\
\text { roreri }\end{array}$ & Latin America & 30 & 47 \\
\hline $\begin{array}{l}\text { Swollen } \\
\text { Shoot }\end{array}$ & CSSV & Africa & 50 & 28 \\
\hline $\begin{array}{l}\text { Vascular- } \\
\text { streak } \\
\text { dieback }\end{array}$ & $\begin{array}{l}\text { Oncobasidium } \\
\text { theobromae }\end{array}$ & Asia & 30 & 28 \\
\hline
\end{tabular}

*January, 2001: value $=\$ 940.00 /$ metric ton.

Source: The World Cocoa Situation, M. Taylor, LMC International Ltd/Trade Discussions (36).

In Brazil, the production of cocoa beans has dropped from 400,000 to 100,000 metric tons in just 10 years, largely as the result of the infection by the fungus, Crinipellis perniciosa. This fungus has spread beyond Brazil into Peru, Ecuador, Venezuela, and Colombia in South America, and Panama in Central America. The pathogen also is on the Caribbean islands of Trinidad and Tobago $(28,31)$.

A second fungus, Moniliophthora roreri, causes another very damaging disease, frosty pod rot, that also destroys the cacao beans inside the pods $(7,11)$. This pathogen has not yet moved into Brazil, but has moved beyond Panama in Central America into Costa Rica and Nicaragua. Vast numbers of air-borne spores of the fungus, that give the pods a frosty appearance, will undoubtedly spread the disease to other cacao growing regions (11).

The disease that causes the most widespread destruction of cacao worldwide is black pod, which is caused by several species of Phytophthora, a fungus-like microorganism that comes in several forms (13). The most widespread species are found around the world in all cacao growing areas, and cause sporatic losses. One species, P. megakarya, is spreading throughout West Africa, the world's premier cacao growing area, and causes major losses (14).

Vascular streak dieback, caused by Oncobasidium theobromae, is found only in Asia $(30,42)$, and swollen shoot virus disease, found only in West Africa $(37,38)$, are of relatively minor importance compared to the other abovementioned diseases (10).

Many factors contribute to a decline in production of cocoa beans worldwide, including insect infestations, social pressures to grow other crops, economic issues that discourage long-term commitment of small acreage farmers to grow the crop, and societal pressures to destroy rain forest environments. Plant diseases are major components of the decline in production. We as plant pathologists and microbiologists have as our mandate to discover and devise means to reduce disease losses and to save chocolate for the enthusiastic consumers of the world. 
Black Pod

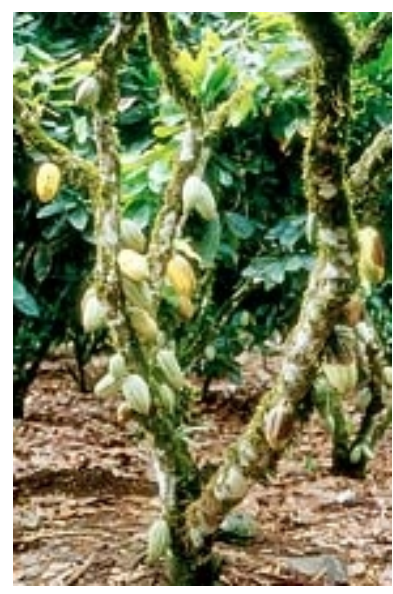

Fig. 5. Cacao tree with healthy pods on the left, and pods with black pod disease on the right.
Black pod disease of cacao is an economically serious problem in all areas of the world where cacao is grown (Fig. 5) $(4,8,10,12,13)$. Annual losses due to black pod may range from $30-90 \%$ of the crop. This disease is especially severe in West and Central Africa which contributes $60-70 \%$ of the world production of cocoa beans. The disease is caused by a complex of species of Phytophthora (the genus named by Anton de Bary in 1876 as "plant destroyer") (5). These pathogens are fungus-like microorganisms with a world-wide distribution. Species of Phytophthora are pathogens on most economically important crops grown throughout the world, such as P. infestans, the cause of late blight of potato (6).

Previously, isolates of Phytophthora from cacao were classified as P. palmivora (Butl.) Butler (4). This species has been recognized as one of the most important pathogens in the tropics attacking many plantation crops, including cacao, rubber, black pepper, coconut, pineapple, and papaya, as well as citrus, avocado, and many ornamental plants. Early studies of the pathogen revealed some variation in the morphology and types of lesions produced on cacao pods among isolates from different countries. In 1976, isolates of P. palmivora from cacao were placed into one of four morphological groups (MF1, MF2, MF3, and MF4) (15). Further studies redefined the morphological groups. The MF1 form was considered to be the typical P. palmivora, and the MF2 form a variant (atypical) of P. palmivora (4). The MF3 form was described as a new species, P. megakarya Brasier and Griffin (4), and the MF4 form considered to be P. capsici Leonian $(39,43)$. Recently, it has been proposed that isolates of P. capsici differing in morphological and pathological attributes should be called $\mathrm{P}$. tropicalis (2). Phytophthora palmivora is present in most countries and is an important part of the black pod complex, while P. megakarya is present only in several countries in West Africa (14). However, P. megakarya appears to be more virulent than P. palmivora and is becoming the dominant species in West Africa, moving from Nigeria and Cameroon into countries where it has not been reported previously. In the major cacao-growing region of Bahia, Brazil, three species have been implicated: P. palmivora, P. capsici, and P. citrophthora (Smith and Smith) Leonian $(17,22,24)$. Phytophthora capsici appears to be the dominant and most important species attacking cacao in Brazil, and also has been reported to occur in other countries in Central and South America, as well as in the West Indies, Indonesia, and India (6). Phytophthora citrophthora is the least common species found in Brazil, but is the most virulent $(17,24)$. Phytophthora heveae Thompson also has been found to cause black pod in some countries (6).

Although Phytophthora species attacks all parts of the cacao plant, the major economic loss is from infection of the pod (Fig.6) $(10,13)$. Pods or cherelles (immature pods) may be infected at any place on the surface, but infection is most often initiated at the tip or stem end. The disease causes a firm, spreading, chocolate-brown lesion that eventually covers the whole pod. The beans inside the pod may remain undamaged for several days after initial infection of the husk, thus frequent harvests may prevent much yield loss. In advanced infections, Phytophthora invades the internal pod tissues and causes discoloration and shriveling of the cocoa beans. Diseased pods eventually become black and mummify. The pathogen also will cause a seedling blight in cacao nurseries as a result of infection of the stem and young leaves (Fig.7). 


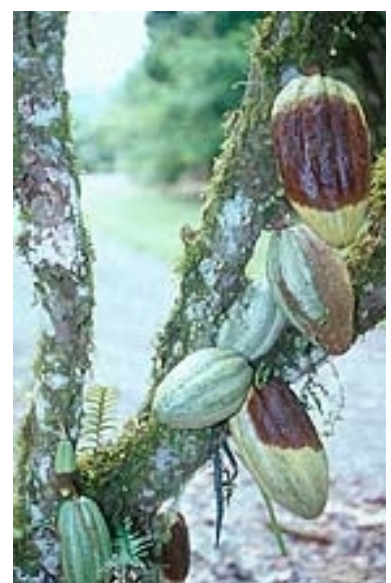

Fig. 6. Black pod disease of cacao caused by P. capsici in Costa Rica.

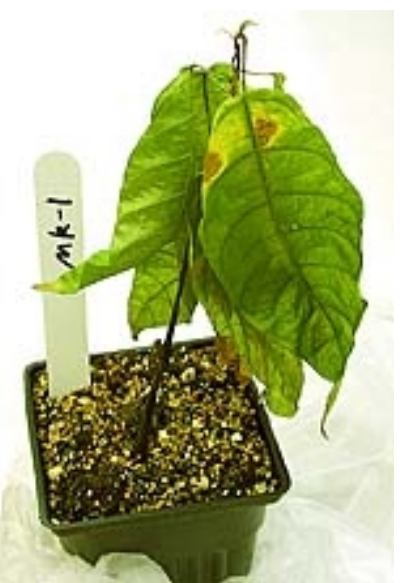

Fig. 7. Seedling blight of cacao caused by $P$. megakarya.

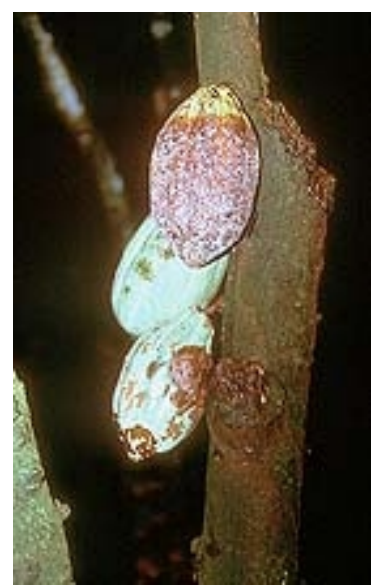

Fig. 8. Sporangia of $P$. megakarya forming on the surface of an infected pod in Cameroon (courtesy Pierre Roger Tondje).
The inoculum that initiates black pod can come from the soil and/ or infected roots, stems, and leaves $(5,10)$. Root infection from residual soil inoculum usually is not an economic concern, however, the pathogen is capable of producing spores on all infected plant parts. Thus, infected roots may serve as a source of inoculum for infection of the pods. Bark and stem cankers may function in the same manner. Once a pod is infected and sporulating, it may then provide a massive source of inoculum to infect other pods.

Under humid conditions, sporangia (asexual reproductive structures and a source of secondary inoculum) may form on the surface of infected roots, cankers, or diseased pods (Fig. 8) (14). This type of propagule can be dispersed by rainfall, splashing water, and water moving over the surface of the soil (5). When sporangia are in free water, zoospores are formed inside the sporangia and released into the water (Fig. 9). Zoospores are motile spores that actively swim towards an infection site and are the primary infective propagules. Thus, windborne rain is a primary factor in the spread of the disease. Ants also have been reported to transport inoculum.

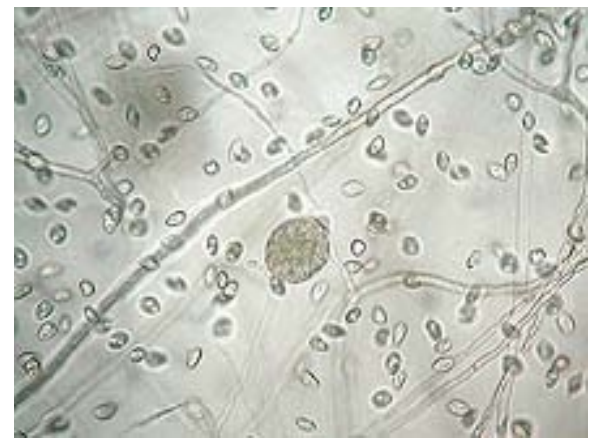

Fig. 9. Sporangium and zoospores of $P$. megakarya.

Control of black pod is difficult because Phytophthora can persist in soil and debris for several years (5). Also, since susceptible pods may be present on the trees most of the year, the pathogen may always be present in the canopy, ready to cause major epidemics when environmental conditions become favorable for sporulation and dispersal (10). Frequent harvesting will lessen the danger of spread of the disease from infected pods (34). Regular pruning to remove 
infected chupons (small suckers at the base of the tree) and increase air circulation (to reduce the humidity under the canopy) is an important disease management tool. Other measures, such as the removal of infected pods and husk piles, may have some effect on inoculum levels. However, under high rainfall conditions, it is difficult to effectively suppress the inoculum to attain good control (10). Chemical control relies on the use of copper and metalaxylbased fungicides. However, these are not entirely effective, are expensive for the small farmer, and not economically feasible (12,27). Additionally, there are environmental concerns regarding the heavy use of chemicals in the tropical rainforests, and there may be problems with non-target effects and resistance of the pathogen. At present, there is no acceptable genetic resistance in cacao to control black pod. Active research is underway throughout the world on this important disease of cacao. Control measures being investigated are aimed at integrated pest management (IPM) strategies, and include biological control microorganisms, genetic and induced resistance, cultural practices, natural products, and limited use of chemicals (18).

\section{Witches' Broom}

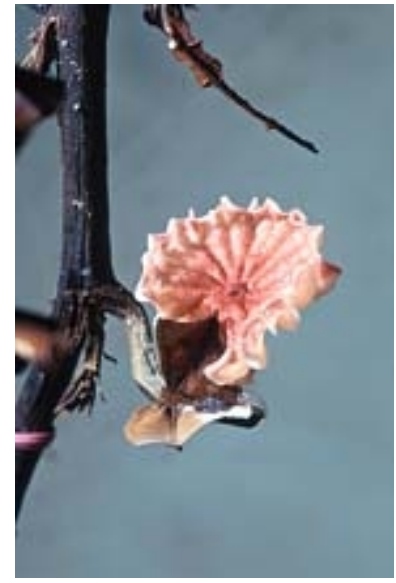

Fig. 10. Basidiocarp of C. perniciosa (courtesy Scott Bauer, ARS Information Staff).
Witches' broom disease, caused by the fungus Crinipellis perniciosa (Stahel) Singer (formerly Marasmius perniciosus), was first reported in 1895 from Surinam and is currently found in several countries of South America and the Caribbean islands $(31,40)$. The disease is initiated by basidiospores produced and released from pinkish mushrooms called basidiocarps (Fig. 10), that are dispersed by wind and rain onto leaves, flowers, and fruit (pods) of cacao plants. It is estimated that a single basidiocarp can release 80 to 90 million basidiospores. In the presence of free moisture (rain and dew) and high relative humidity, basidiospores germinate and penetrate young meristematic tissues in vegetative and floral buds through stomata, epidermis, or trichomes. The colonized tissues undergo several physiological and hormonal changes leading to swelling and formation of numerous succulent vegetative branches, known as brooms, within flower cushions (Fig. 11) and on vegetative apical (Fig. 12) or axillary buds (26). The brooms are usually formed within 5 to 6 weeks following infection. The fungus also infects pods causing necrotic lesions, uneven ripening, and various deformations. Brooms and infected pods become progressively brown and dry, and within 3 to 8 months following broom and pod drying, basidiocarps (Fig. 13) are formed following several alternating wet and dry periods.

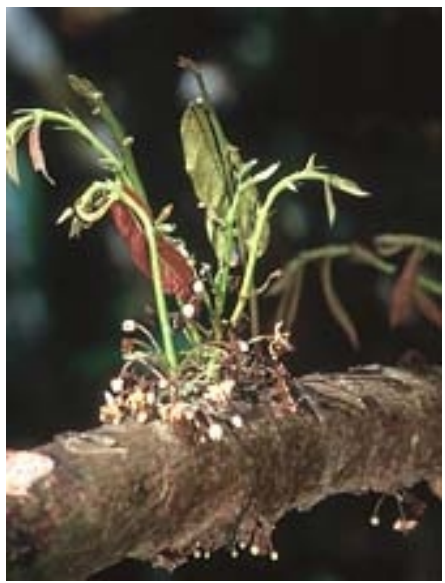

Fig. 11. Vegetative branches (brooms) arising from a flower cushion infected by $\mathrm{C}$. perniciosa. 


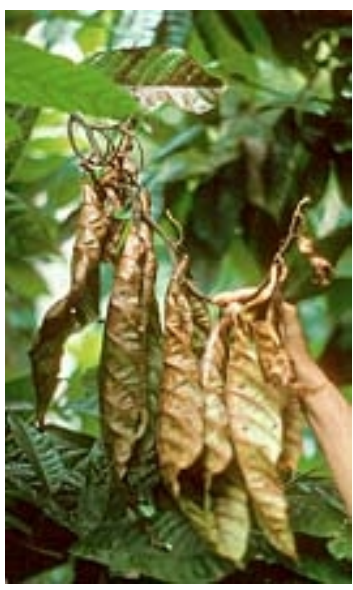

Fig. 12. A dry broom formed from infection of an apical vegetative bud by C. perniciosa.

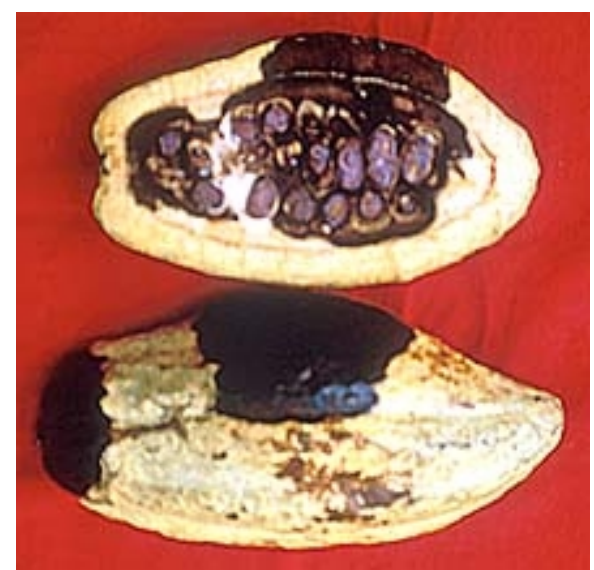

Fig. 14. Cacao pod infected with C. perniciosa showing lesion on the surface and extensive rotting of the seeds (courtesy Jose Rondon and Orlando Arguello).

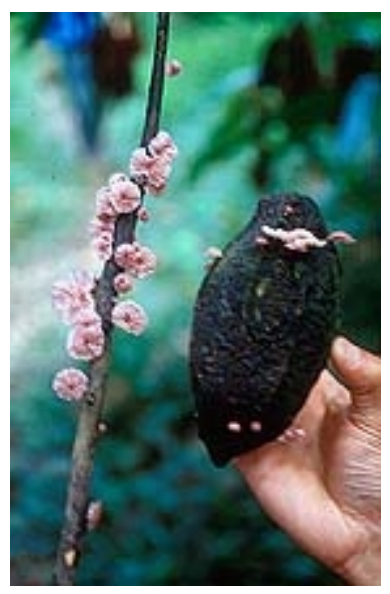

Fig. 13. Basidiocarps (pinkish structures) formed on a dry broom and pod infected with C. perniciosa.

Witches' broom debilitates cacao trees by diverting energy to the numerous brooms that do not form flowers, thus reducing yield potential. Further yield loss is incurred by the prevention of seed formation in pods infected early in their development. If seeds are formed prior to infection they may be unusable depending on the extent of pod colonization by $\mathrm{C}$. perniciosa (Fig. 14).

In its natural habitat of the Amazonian forest, cacao is found as scattered under story trees which are genetically variable, a characteristic that hampers the development of epidemics of witches' broom. The cultivation of cacao has intensified over the years as cocoa has progressively become a global trade commodity.

Production environments that encourage the planting of cacao varieties with little genetic diversity ensures a constant supply of susceptible tissue for infection by C. perniciosa.

Management of witches' broom has received considerable attention from the beginning of the 20th century $(10,12,28,31,40)$. Broadly, there are four major strategies that may be adopted: phytosanitation, chemical control, genetic resistance, and biological control (18). Phytosanitation, by removal and destruction of diseased plant parts, has been shown to reduce pod loss and delay disease epidemics $(32,34)$. However, this strategy is tedious and in one study it has been shown that 95\% removal is required to achieve $50 \%$ reduction in pod loss (32). Chemical control of witches' broom with protectant and systemic fungicides is not a routine practice in cocoa production because of high costs and risks associated with cocoa bean contamination and environmental health (10). The development of genetically resistant cacao cultivars is an on-going endeavor in many countries, and it is expected that the use of these cultivars would reduce the incidence of the disease.

Prospects of managing witches' broom disease of cacao through biological control have been investigated for over 20 years leading to the isolation of a new species, Trichoderma stromaticum, a parasite on the mycelium and basidiocarps of C. perniciosa (33). In Brazil, commercial formulations of T. stromaticum are currently used in managing witches' broom. However, the inconsistent performance of $\mathrm{T}$. stromaticum indicates the need to further understand the relationship between the cacao plantation environment and the 
survival and establishment of this mycoparasitic fungus. Collaborative research efforts by scientists at research institutions in the United States and Central and South America are currently underway to optimize the use of T. stromaticum.

Frosty Pod Rot

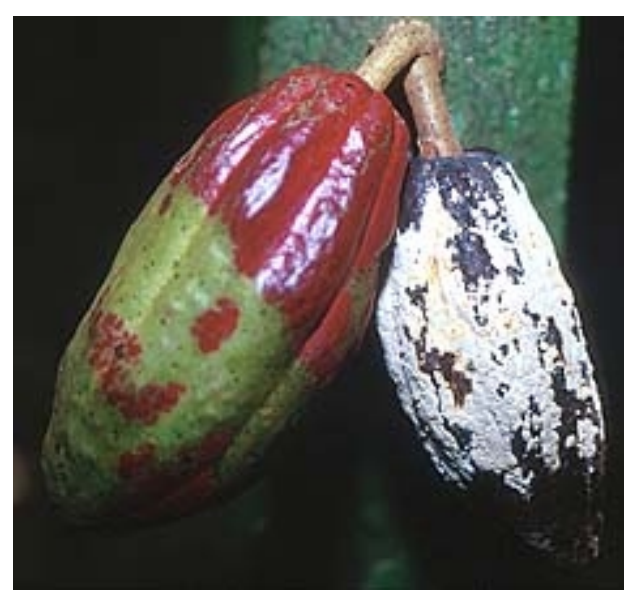

Fig. 15. Frosty pod rot of cacao caused by $M$. roreri with whitish to creamy-colored spores on the pod surface.
Frosty pod rot (or Moniliophthora pod rot), caused by Moniliophthora roreri (Ciferi \& Parodi) Evans et al., originally described in 1933 as Monilia roreri, is a devastating disease of cacao pods $(7,11)$. The conidia (the only known infective propagules) infect by penetrating the surface of the pods. The pods are highly susceptible during the first 90 days of their growth. Early symptoms include discolored areas of swelling on the pods followed by a dense formation of cream-colored spores, the so called frosty pod, developing on the pod surface within 2 weeks after infection (Fig. 15). The area of the pod with sporulation spreads rapidly, and spore densities have been

estimated to be as high as 44 million conidia per square centimeter $(7,12)$. The spores are later released by wind or by water droplets during rainy periods.

Frosty pod rot occurs on all Theobroma and related Herrania species. The first report of the disease was by J. B. Rorer (1917-1925) while on a scientific trip to Ecuador to investigate serious losses in yields due to diseases (7). Frosty pod rot currently is restricted to northwest South America (Ecuador, Peru, Colombia) and south Central America (Nicaragua, Costa Rica and Panama). However, it is an immediate threat to Brazil, which is one of the largest cacao growing areas in South America. Yield losses have been estimated between 25\% to total loss of the crop if frequent (7-10 day schedules) phytosanitary measures are not implemented (34). The most economical way of controlling the spread of this disease is to eliminate the inoculum sources, which are dead sporulating pods (Fig. 16), with frequent harvests on regular cycles (32). Other practices should include reduction of tree height (maximum $3.5 \mathrm{~m}$ ) to facilitate removal of diseased pods, biological control, and planting of resistant or tolerant cultivars as they become available.

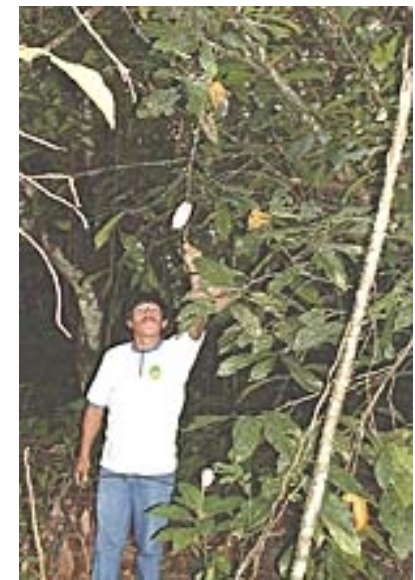

Fig. 16. Trees in abandoned plantations where the presence of dead pods covered with spores of $M$. roreri is a constant source of inoculum. 


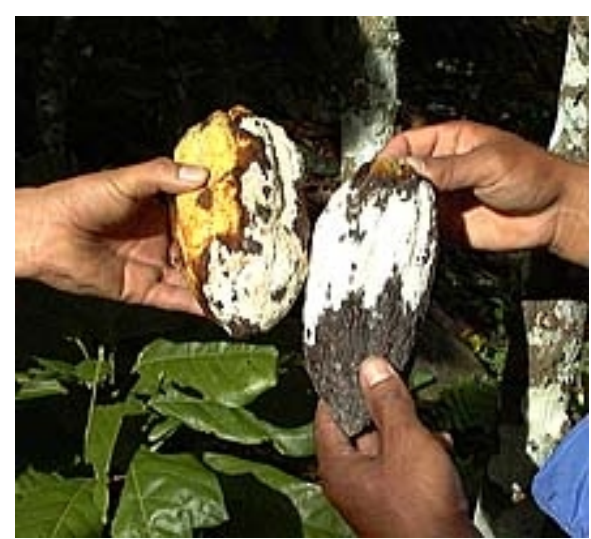

Fig. 17. Infected pod sprayed with biocontrol agents (left) reduce spore dispersal by parasitizing the pathogen mycelium and spores (note the creamcolored, parasitized spores). The pod on Soberanis and H. Gomez, SENASA, Peru). the right was not sprayed (courtesy W.

In view of the difficulty in finding a practical and cost-effective fungicidal treatment, alternative control strategies, such as biological control are being investigated in Peru, Panama, and Costa Rica to manage frosty pod $\operatorname{rot}(18,19,20,34)$. This involves the use of naturally occurring fungal agents (mycoparasites) capable of parasitizing the pathogen and preventing the dispersal of fungal spores (Fig. 17). Saprophytic fungi belonging to the genus Trichoderma and Clonostachys, selected for their parasitizing capacity, are being tested in field trials (29). Biweekly to monthly sprays of biocontrol agents have been shown to reduce the production of conidia on diseased pods (19). Biocontrol treatment along with phytosanitation has reduced pod loss and increased yields in previously abandoned cacao plantations (19).

Major genetic improvement efforts are underway in Costa Rica, Colombia, and Ecuador to select genotypes resistant or tolerant to M. roreri, and new hybrid clones are being distributed to farmers (Fig. 18). Breeding for disease avoidance may be one of the safest methods to reduce field losses, as this form of resistance is less vulnerable to adaptive changes by the pathogens. For example in Ecuador, disease losses due to $\mathrm{M}$. roreri were found to be lower in trees that bring a high proportion of their total pods to maturity during the later months of the dry seasons or early wet season, thus avoiding conditions that favor disease development (9).

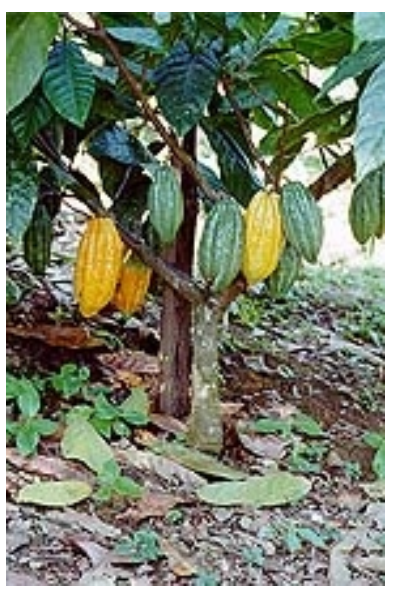

Fig. 18. A cacao clone from a breeding program in Columbia (courtesy Jose Rondon and Orlando Arguello). 


\section{Genetic and Induced Resistance in Cacao}

Cacao is an open pollinated (cross

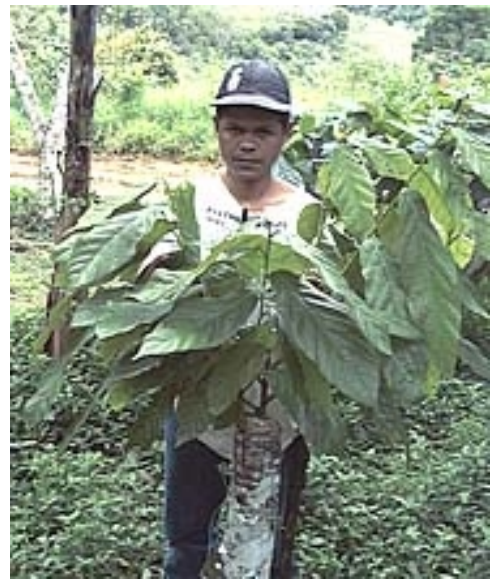

Fig. 19. A young cacao tree produced by grafting resistant budwood onto susceptible rootstock. breeding) species. This poses difficulties when trying to improve such characteristics as bean quality and yield, or disease and insect resistance in cacao. Individual trees bearing beneficial traits fail to produce offspring that consistently bear the same traits. When farmers select seed from their best trees, the resulting trees are often of poor quality, produce low yields and are susceptible to diseases and insects. The only way to produce trees of uniform high quality is by vegetative propagation resulting in exact clones of the parent tree. A number of vegetative propagation methods have been developed. These include low-tech rooted cuttings and grafting techniques (Fig. 19) as well as hightech tissue culture and micropropagation techniques (Fig. 20) (23). Unfortunately, high-tech solutions are expensive, requiring government or industry support, and lowtech solutions are slow. Considering the intensive pressure from diseases and insects on the world cacao crop, these techniques fail to meet the farmers' needs for high quality seedlings. A combination of low-tech and high-tech methods has been worked out and offers hope for the production of large numbers of high quality seedlings in the future.

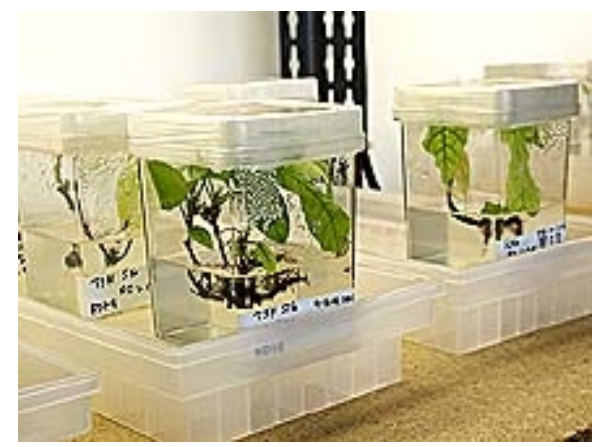

Fig. 20. Cacao plantlets produced in tissue culture.

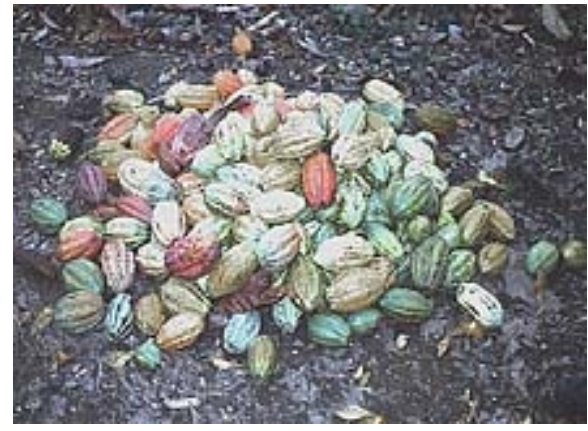

Fig. 21. A mixture of pods showing the genetic diversity in a planting of cacao.
There is great potential for accelerating the improvement of cacao using traditional plant breeding enhanced by molecular genetics techniques (21). These techniques allow breeders to maintain and combine important agronomic traits controlled by many genes, such as yield and disease resistance, in their breeding populations, and produce new varieties for release with fewer generations to farmers. Breeders often have limited access to the best germplasm sources. Some of the sources may have yet to be discovered in wild populations in South and Central American forest or may be located in collections separated by great distances and national boundaries. Through international collaborations, scientists using molecular techniques are attempting to catalogue and characterize the genetic diversity in the world's cacao populations, including both wild and cultivated populations. It is estimated that there are 18,000 cacao accessions in collections worldwide, and these accessions can be grouped into 2500 to 3000 genetic groups (Fig. 21). An 
additional 300 to 500 genetic groups may exist in wild populations. As more is learned about the world's cacao populations, we should be better able to exploit this valuable resource to improve not only production of chocolate, but the lives of many small farmers dependent on cacao production worldwide. The combination of modern plant breeding and plant propagation techniques should allow these improvements to have an impact on global cacao production more rapidly than ever thought possible in the past.

The genetic control of disease

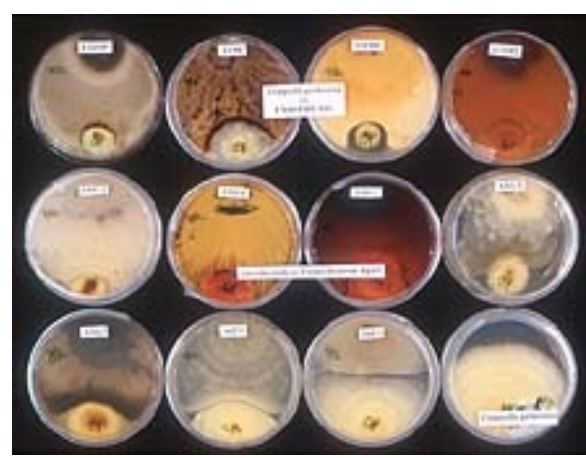

Fig. 22. Fungal endophytes being studied for their ability to control diseases on cacao. resistance traits can be simple, involving a single gene, or complex, involving many genes. Resistance to disease in cacao has been identified in some cases, but limitations to increasing the number of trees carrying those traits prevent their wide spread use. In addition, pathogen populations differ between cacao production areas, so resistance that is effective in one area may totally fail to provide disease control in another area. Novel disease control methods such as biological control using beneficial microorganisms (Fig. 22), in some cases, can function regardless of the genetic background (16,33). Biocontrol offers a potential control strategy for the cacao trees presently under cultivation. Most, if not all, plant species possess the ability to resist disease development. Disease develops when the plant's defense mechanisms are not activated. This phenomenon has provided the rationale behind the development of a new class of disease control compounds that activate plant defense mechanisms allowing an otherwise susceptible plant to protect itself $(25,35)$. These types of compounds are now being tested for disease management in cacao (1).

Some of the same factors that limit the potential for using traditional chemical control measures limit the use of biocontrol. Cacao is often grown in remote areas and as an understory tree. This situation, combined with the low market value for the product and the high cost of supplies and labor, often make any disease control strategy requiring regularly scheduled applications financially impractical. Perhaps an optimum disease management strategy would be to identify beneficial microorganisms that persist in the cacao canopy and root systems and provide disease control without regular spray applications. These types of organisms, epiphytes, endophytes, and mycorrhizae exist in cacao and are currently being studied for their beneficial effects (3). It is possible that microorganisms that induce resistance to disease and insects in cacao can be identified. The use of these microorganisms could result in long term disease control with limited cost to the farmer and could actually be beneficial to the environment.

\section{Sustainable Cacao Production}

The chocolate industry is keenly aware of the requirement for an adequate supply of cocoa beans of consistent quality. Therefore, it is essential that the industry and all its associated institutions and interests support scientific research on cacao and its products in key areas such as production, integrated pest and disease management, germplasm conservation and improvement, and biotechnology. The cacao research community is international in scope. Industry, trade organizations, government, and non-government organizations support the comprehensive effort to address ecological, social, pest and disease management, economic, and cacao improvement concerns. The USDA/ ARS alone has formal and informal research agreements with many organizations, including those listed in Table 2, and with other government and nongovernment organizations, and universities. 
Table 2. Organizations with formal or informal research agreements with USDA/ARS.

\begin{tabular}{|l|l|}
\hline Organization & Country \\
\hline ACRI & USA \\
\hline M\&M MARS CORP. & USA \\
\hline USAID & USA \\
\hline CICAD & OAS \\
\hline CABI-BIOSCIENCE & UK \\
\hline SENASA & Peru \\
\hline CEPLAC/CEPEC & Brazil \\
\hline CORPOICA & Colombia \\
\hline CATIE & Costa Rica \\
\hline IRAD/IITA & Cameroon \\
\hline Smithsonian Inst (STRI) & Panama \\
\hline University of Maryland & USA \\
\hline Penn State University & USA \\
\hline D2 Biotechnologies & USA \\
\hline
\end{tabular}

To this end, the basis of such an initiative is the development and promotion of sustainable cacao agriculture, defined by The American Cocoa Research Institute (ACRI) as, "...the production practices in which the small acreage farmer increases or maintains productivity at levels that are economically viable, ecologically sound, and culturally acceptable, through the efficient management of resources."

Cultivation of cacao within a sustainable, biologically diverse agricultural system also provides habitat to important forest and migratory bird and mammal species (41). In Central and South America and in Africa, strategic preservation of rain forest remnants and the development of forest links have offered hope to efforts to preserve rain forest environments. Sustainable cacao will not only help the cocoa and chocolate manufacturers maintain a constant and reliable supply of raw material, but it also will aid in the global efforts to conserve tropical forest ecosystems and move small holder farmers into a more favorable economy.

According to Young (41), prehistoric peoples in Mesoamerica had the correct approach to farming cacao. Relatively small cacao orchards enclosed by forest or set within small, diversified plots of various crops within the forest optimized the chances for high productivity. Pollination and containment of diseases and insects under these conditions may have been better than what is typically found in large, monoculture-type plantations today. The challenges of disease epiphytotics, insect infestations, poor pollination, and chemical fertilization were minimized because of the practices of the Mayans, Aztecs, and other mesoamerican people. They knew that growing "the food of the gods" in small groves reaped considerable harvests.

Understanding the components of cacao crop management is essential to growing sustainable cacao. The impact of diseases such as black pod, witches' broom, and frosty pod rot will continue to be devastating until progress is made to control these diseases. Short term solutions such as chemical fungicides are often cost-prohibitive, may be damaging to the environment, and leave undesirable residues in the product. Long term solutions such as biotechnological approaches or breeding for disease resistance are timeconsuming to develop and are not readily available for immediate application. The most immediate answer to the disease problems is to use what tools are 
presently available in an integrated approach. These include limited biological control methods, disease resistant material, crop sanitation to remove diseased material as a source of inoculum, and cultural practices such as shade optimization, pruning, and soil fertility management.

As stated by Young (41), the cacao tree is truly a creature of nature and is cultivated in a relatively primitive way compared to modern row crop agriculture. It may be compelling to protect the tropical ecosystems that are still left to ensure the world's coveted supply of chocolate and at the same time preserve many more biological riches integrated into the complex fabric of tropical diversity.

\section{Literature Cited}

1. Aneja, M., and Gianfagna, T. 2001. Induction and accumulation of caffeine in young, actively growing leaves of cocoa (Theobroma cacao L.) by wounding or infection with Crinipellis perniciosa. Physiol. Mol. Plant Path. (in press).

2. Aragaki, M., and Uchida, J. Y. 2001. Morphological distinctions between Phytophthora capsici and P. tropicalis sp. nov. Mycologia 93:137-145.

3. Arnold, B. 1999. Fungal Endophytes of Tropical Trees: Methods and Potential for Biological Control of Fungal Pathogens of Cocoa, Workshop Manual, CATIE, Turrialba, Costa Rica, 28 J une-4 J uly, 1999.

4. Brasier, C. M., and Griffin, M. J . 1979. Taxonomy of Phytophthora palmivora of cocoa. Trans. Br. Mycol. Soc. 72:111-143.

5. Erwin, D. C., Bartnicki-Garcia, S., and Tsao, P. H., eds. 1983. Phytophthora: Its Biology, Taxonomy, Ecology, and Pathology. American Phytopathological Society, St. Paul, MN.

6. Erwin, D. C., and Ribeiro, O. K. 1996. Phytophthora Diseases Worldwide. American Phytopathological Society, St. Paul, MN.

7. Evans, H. C. 1981. Pod rot of cacao caused by Moniliophthora (Monilia) roreri. Phytopathol. Pap. 24. Commonw. Mycol. Inst., Kew, Surrey, England.

8. Evans, H. C. 2001 Risk assessment of fungal biocontrol agents of weeds and plant diseases. BMS International Symposium on Bioactive Fungal Metabolites, University of Swansea, 22-27 April.

9. Evans, H. C., Edwards, D. F., and Rodriguez, M. 1977. Research on cocoa diseases in Ecuador: past and present. PANS 23:68-80.

10. Evans, H. C., and Prior, C. 1987. Cocoa pod diseases: causal agents and control. Outlook on Agriculture 16:35-41.

11. Evans, H. C., Stalpers, J. A., Sampson, R. A., and Benny, G. L. 1978. On the taxonomy of Monilia roreri, an important pathogen of Theobroma cacao in South America. Can. J. Bot. 56:2528-2532.

12. Fulton, R. H. 1989. The cacao disease trilogy: black pod, monilia pod rot, and witches'-broom. Plant Disease 73:601-603.

13. Gregory, P. H., ed. 1974. Phytophthora Diseases of Cocoa. Longman, London.

14. Gregory, P. H., and Maddison, A. C., eds. 1981. Epidemiology of Phytophthora on Cocoa in Nigeria. Commonw. Mycol. Inst. Kew. Phytopathol. Pap. No. 25.

15. Griffen, M. J. 1977. Cocoa Phytophthora Workshop. Rothamsted Experimental Station, England, 24-26 May, 1976. PANS 23:107-110.

16. Holmes, K. A., Thomas, S. E., and Evans, H. C. 2000. The Search For Biocontrol Agents of Basidiomycete Pathogens (Moniliophthora roreri and Crinipellis perniciosa) of Cacao (Theobroma cacao). BMS Tropical Mycology, J ohn Moores University, Liverpool, 25 - 29 April.

17. Kellam, M. K., and Zentmyer, G. A. 1986. Morphological, physiological, ecological, and pathological comparisons of Phytophthora species isolated from Theobroma cacao. Phytopathology 76:159-164.

18. Krauss, U., and Hebbar, P. 1999. Research Methodology in Biocontrol of Plant Diseases. Workshop Manual. CATIE, Turrialba, Costa Rica, 28 J une-4 J uly, 1999.

19. Krauss, U., and Soberanis, W. 2000. Biological control of frosty pod (Moniliophthora roreri) and other pod pathogens in Peru. Paper presented at $13^{\text {th }}$ Int. Cocoa Research Conf., Kota Kinabalu, Sabah, Malaysia, 9-14 October, 2000.

20. Krauss, U., Soberanis, W., and Matthews, P. 1999. The use of antagonist mixtures in biocontrol. Pages 112-122, in Research Methodology in Biocontrol of Plant Diseases with Special Reference to Fungal Diseases of Cocoa. U. Krauss and K. P. Hebbar, eds. CATIE, Costa Rica.

21. Lanaud, C., Risterucci, A. M., Pieretti, I., Falque, M., Bouet, A., and Lagoda, P. J . 1999. Isolation and characterization of microsatellites in Theobroma cacao. Mol. Ecol. 8:2141-2143.

22. Lawrence, J. S., Luz, E. D. M. N., and Resnik, F. C. Z. de. 1982. The relative virulence of Phytophthora palmivora and P. capsici on cacao in Bahia, Brazil. Revista Theobroma 12:189-198. 
23. Li, Z., Traore, A., Maximova, S., and Guiltinan, M. J . 1998. Somatic embryogenesis and plant regeneration from floral explants of cacao (Theobroma cacao L.) using thidiazuron. In Vitro Cell. Dev. Biol.- Plant 34:293-299.

24. Luz, E. D. M. N., and Campêlo, A. M. F. L. 1984. Equilíbrio populacional das espécies de Phytophthora responsáveis pela podridao-parda na Bahia, Brasil. Pages 279-286 in: Proc. 9th Int. Cocoa Res. Conf., Lome, Togo, 12-18 Feb., 1984.

25. Oostendorp, M., Kunz, W., Dietrich, B., and Staub, T. 2001. Induced disease resistance in plants by chemicals. European J of Plant Pathology 107: 19-28.

26. Orchard, J., Collin, H. A., Hardwick, K., and Isaac, S. 1994. Changes in morphology and measurement of cytokinin levels during the development of witches' brooms on cocoa. Plant Pathology 43:65-72.

27. Pereira, J . L. 1985. Chemical control of Phytophthora pod rot of cacao in Brazil. Cocoa Growers Bull. 36:23-38.

28. Pereira, J . L. 1996. Management of Witches' Broom Disease of Cocoa: A Contemporary Retrospective. Cocoa Producers' Alliance, 8/ 10 Broad Street, P.O. Box 1718, Lagos, Nigeria.

29. Piper, S., Martínez, A., Hidalgo, E., and Krauss, U. 2000. Effect of formulation on population dynamics of mycoparasites on the surface of cocoa pods. Paper presented at the INCOPED 3rd Int. Seminar on Cocoa Pest and Diseases, Kota Kinabalu, Sabah, Malaysia, 16-17 October, 2000.

30. Prior, C. 1980. Vascular streak dieback. Cocoa Growers' Bull. 29:21-26.

31. Purdy, L. H., and Schmidt, R. A. 1996. Status of cacao witches' broom: biology, epidemiology, and management. Annu. Rev. Phytopathol. 34:573-594.

32. Rudgard, S. A., and Butler, D. R. 1987. Witches' broom disease in Rondonia, Brazil: pod infection in relation to pod susceptibility, wetness, inoculum, and phytosanitation. Plant Pathology 36:515-522.

33. Samuels, G. J., Pardo-Schultheiss, R., Hebbar, K. P., Lumsden, R. D., Bastos, C. N., Costa, J. C., and Bezerra, J . L. 2000. Trichoderma stromaticum, sp. nov., a parasite of the cacao witches broom pathogen. Mycol. Res. 104:760-764.

34. Soberanis, W., Ríos, R., Arévalo, E., Zúniga, L., Cabezas, O., and Krauss, U. 1999. Increased frequency of phytosanitary pod removal in cacao (Theobroma cacao) increases yield economically in eastern Peru. Crop Protection 18:677-685.

35. Sticher, L., Mauch-Mani, B., and Metraux, J. P. 1997. Systemic acquired resistance. Ann. Rev. Phytopathol. 35:235-270.

36. Taylor, M. 1998. The World Cocoa Situation. International Forum in Cocoa, Lima, Peru, 28-29th October, 1998. LMC International, Ltd., London, UK.

37. Thresh, J. M., Owusu, G. K., Boamah, A., and Lockwood, G. 1988. Ghanaian cocoa varieties and swollen shoot virus. Crop Protection 7:219-231.

38. Tinsley, T. W. 1971. The ecology of cacao viruses. I. The role of wild hosts in the incidence of swollen shoot virus in west Africa. J . Appl. Ecol. 8:491-495.

39. Tsao, P. H., and Alizadeh, A. 1988. Recent advances in the taxonomy and nomenclature of the so-called "Phytophthora palmivora" MF4 occurring on cocoa and other tropical crops. Proc. 10th Int. Cocoa Res. Conf., Santo Domingo, Dominican Republic, 17-23 May, 1987. Cocoa producers Alliance.

40. Wheeler, B. E. J., and Suárez, C. 1993. The pathosystem. Pages 9-19 in: Disease Management in Cocoa. Comparative epidemiology of witches' broom. S. A. Rudgard, A. C. Maddison, and T. Andebrhan, eds. Chapman \& Hall.

41. Young, A. M. 1994. The Chocolate Tree: A Natural History of Cacao. Smithsonian Institution Press, Washington and London.

42. Zainal Abidin, M. A., Varghese, G., and Mainstone, B. J . 1981. Vascular streak dieback of cocoa in Malaysia. I. A survey of its incidence and identification of the pathogen involved. The Planter 57:3-13.

43. Zentmyer, G. A., Kaosiri, T., Idosu, G. O., and Kellam, M. K. 1981. Morphological forms of Phytophthora palmivora. Pages 291-295 in: Proc. 7th Int. Cocoa Res. Conf, Douala, Cameroon, 4-12 Nov., 1979. J . de Lafforest, ed. Transla-Inter Ltd, London. 
Electronic Resources for Further I nformation

The American Cocoa Research Institute

International Cocoa Organization

Cacao Integrated Pest Management - Ohio State University

Cocoa

Blackpod

Witches' Broom

Monilia Pod Rot

Theobroma cacao - Purdue University - Center for New Crops \& Plant Products

Theobroma cacao - University of Louisiana

Diseases of Cacao - Common Names of Plant Diseases

Chocolate Information Center - Mars, Inc.

Cacao - Science Museum of Minnesota 